\title{
Investigating the Texture and Antioxidant Capacity of Papain and Trans-glutaminase Enzyme-treated Yogurt with Different Carbohydrates - Glucose, Sucrose and Maltodextrin
}

\author{
Attila Csighy*, Arijit Nath¹, Eszter Vozáry², András Koris , Gyula Vatai \\ ${ }^{1}$ Department of Food Engineering, Faculty of Food Science, Szent István University, H-1118 Budapest, Ménesi út 44, Hungary \\ 2 Department of Physics and Control, Faculty of Food Science, Szent István University, H-1118 Budapest, Somlói út 14-16, Hungary \\ * Corresponding author, e-mail: csighy.attila@gmail.com
}

Received: 30 September 2019, Accepted: 20 February 2020, Published online: 08 May 2020

\begin{abstract}
Yogurt is considered as a functional food, which is a complex mixture of different biological components. Functional foods are designed to have physio-logical benefits and reduce the risk of chronic diseases beyond basic nutritional functions, and may be similar in appearance of conventional food. Therefore, the consumption of dairy products is highly recommended. In this study, the average composition milk was purchased in a local supermarket. Subsequently, ultrafiltration of milk was carried out with a tubular membrane, placed in a laboratory-developed cross-flow membrane module. Pore size and active surface area of tubular membrane were $5 \mathrm{~nm}$ and $0.005 \mathrm{~m}^{2}$, respectively. A static turbulence promoter was placed inside of membrane tube. Retentate of ultrafiltration membrane was treated with different concentrations of papain at temperature $50^{\circ} \mathrm{C}$ for 10 minutes and subsequently, deactivation of enzymatic activity was performed at temperature $70^{\circ} \mathrm{C}$ for 20 minutes. After deactivation of catalytic activity of papain, milks were fermented with yogurt starter culture (Thermophilic YoFlex $®$ culture) at temperature $45^{\circ} \mathrm{C}$ for 6 hours. During fermentation, transglutaminase and different types of carbohydrates, such as glucose, maltodextrin and sucrose were introduced with the aid of changing texture and antioxidant capacity of yogurt. Antioxidant capacity and hardness of yogurt, prepared with cow's milk were $0.44 \mathrm{mmol}$ eqv. ascorbic acid/L and 0.58 Newton, respectively. It was found that application of enzyme (both papain and transglutaminase) and maltodextrin increased the antioxidant capacity of yogurt. Furthermore, it was found that hardness of yogurt was increased by addition of carbohydrate.
\end{abstract}

Keywords

yogurt, papain, transglutaminase, antioxidant capacity, hardness

\section{Introduction}

Yogurt is a well-known fermented milk product, which is a heterogeneous system of carbohydrate, protein and fat. It is produced by the anaerobic fermentation of milk with starter cultures, mostly Lactobacillus bulgaricus and Streptococcus thermophilus. When an adequate amount of lactic acid is produced, the milk proteins coagulate. This coagulated milk is known as yogurt. There are two types of yogurt i.e. set yogurt and stirred yogurt. The functional food sector has great possibility in the field of product development [1]. Milk proteins are good sources of bioactive peptides. Enzymatic hydrolysis of proteins is frequently used for the generation of bioactive peptides from protein molecules. Bioactive peptides have positive impact on wide range of health benefits. They can control and modulate important physiological functions through their countless activities, such as antimicrobial, antihypertensive, antithrombotic, immunomodulatory and antioxidant activities [2]. Cow's milk allergenicity is a very complex disorder with different immune reactions. Immunemediated reactions may be IgE-mediated or non-Ig-mediated, whereas food intolerance may be different in every geographical regions. Most of the IgE-mediated allergy occurs in young children in the first 6 months. Milk allergy depends on the characteristics of the population, e.g. geographical origin, atopic status and age. The Cow's milk is a member of the "Big-8" food allergens. Cow's milk contains $30-35 \mathrm{~g} / \mathrm{L}$ of protein. After the acidification, two fractions are generated i.e. lactoserum (whey) and coagulum. The major milk allergens are $\alpha$ s1-casein, $\alpha$-Lactalbumin and $\beta$-Lactalbumin [3, 4]. Milk contains numerous amounts of equol, which is a metabolite of daidzein. The equol offers antioxidant capacity in milk. Furthermore, milk proteins $(\alpha-$, $\beta$ - and $\kappa$ - caseins) offer antioxidant capacity in milk $[5,6]$. 
Acid whey formation during the yogurt production creates main problem for the development of texture of yogurt. The acceptance of yogurt is better when the acid whey is removed [7]. Centrifugation as well as several filtration methods, such as Ultrafiltration (UF) and Reverse Osmosis (RO) are used to concentrate proteins and subsequently yogurt preparation. Application of concentrated milk proteins during yogurt preparation increases quality product with high protein concentration and enhance the gelstrength of yogurt [8]. The problems associated with size exclusion-based membrane filtration process are generation of concentration polarization on membrane surface as well as membrane fouling. Generation of concentration polarization on membrane surface is the cause of severe flux declination, which affect the quality of product $[9,10]$. To reduce the chance of membrane fouling during filtration process, it is important to increase the turbulence intensity on vicinity of membrane surface with the use of static turbulence promoter [11]. The enzymatic modification of proteins by use of microbial transglutaminase and papain offers unique physical and chemical properties of food products. Recently, it has been reported that microbial transglutaminase improves the yogurt texture, i.e. it increases hardness and gel-strength of yogurt. Furthermore, application of transglutaminase increases the viscosity and preventing of whey separation from yogurt [12] The transglutaminase is a transferase enzyme, which promotes cross-linking of amino acid residues (like lysine and glutamine) of protein chain $[12,13]$. The papain is an endopeptidase enzyme, extracted from the fruit of Carica papaya. Papain belongs to the cysteine protease family, which cannot generate bitter taste of food products [14]. This enzyme is relatively heat stable. The molecular weight of papain enzyme is $23,406 \mathrm{Da}$ with 8.75 isoelectric point. Optimum catalytic activity is at $\mathrm{pH} 5-8$. In food industry, papain is used for to produce protein hydrolysate. In juice and brewing industries, papain is used for clarification of juice and fermentation broth [15].

Object of this study was investigating the texture and antioxidant capacity of papain and trans-glutaminase enzyme-treated yogurt with different carbohydrates, such as glucose, sucrose and maltodextrin.

\section{Material and methods}

\subsection{Material}

Extended self-life type of cow's milk was purchased in a local supermarket (G-Roby, Hungary). A freeze-dried yogurt culture (FD-DVS YF-L812 Yo-Flex ${ }^{\circledR}$ ) was procured from Chr. Hansen, Denmark. This yogurt culture contains Lactobacillus delbrueckii subsp. bulgaricus and Streptococcus thermophilus strains. The culture can produce set and drinking-type of yogurt with very mild flavor and extra high viscosity. Microbial transglutaminase (activity $100 \mathrm{U} / \mathrm{g}$ ) from Barentz Ltd., Hungary, papain (nominal activity: $30000 \mathrm{U} / \mathrm{mg}$ ) from HiMedia Laboratories, India were purchased. Ascorbic acid and 2,4,6 Tri(2-pyridyl)-triazine from HiMedia Laboratories, India, sodium acetate, iron (III) chloride, citric acid and acetic acid from Merck, Germany were procured. Ultrasil P3-11 was purchased from Ecolab-Hygiene Kft, Hungary.

\subsection{Methods}

The detailed process flow diagram of the yogurt preparation is shown in Fig. 1. In first step, milk was concentrated with $5 \mathrm{~nm}$-pore-sized membrane and subsequently, retentate of filtration process was collected at aseptic condition. Concentrated milk was treated with papain and after deactivation of catalytic activity of papain, it was fermented with yogurt starter culture. Effects of transglutaminase and different types of carbohydrates, such as glucose, maltodextrin and sucrose during fermentation were studied.

\subsubsection{Membrane filtration}

In this study, the first step was the pre-concentration of milk using $5 \mathrm{~nm}$-pore-sized ceramic membrane. The tubular membrane was placed inside the laboratory-developed membrane house, designed by the Department of Food Engineering, Szent István University, Hungary. Detailed description of membrane module is mentioned elsewhere [16]. Inside the membrane tube, static turbulence promoter was placed. Concentrate milk was prepared by batch-mode filtration process until Volumetric Concentration Ratio (VCR) was achieved 2. The Volumetric Concentration Ratio was determined according to Eq. (1):

$\mathrm{VCR}=\frac{\text { Initial feed volume }}{\text { Concentrate volume }}$.

The permeate flux was calculated according to Eq. (2) [17]:

$J=\frac{V}{A \times t}$,

where $J$ is the permeate flux $\left[\mathrm{L} /\left(\mathrm{m}^{2} \times \mathrm{h}\right)\right], V$ is volume [L], $A$ is active membrane surface $\left[\mathrm{m}^{2}\right], t$ is time [s]. The effective area of the membrane was $0.005 \mathrm{~m}^{2}$. The $3 \mathrm{~L}$ of milk sample was poured in feed tank of membrane module and filtration experiment was performed until $1.5 \mathrm{~L}$ permeate was achieved. Filtration process was performed 


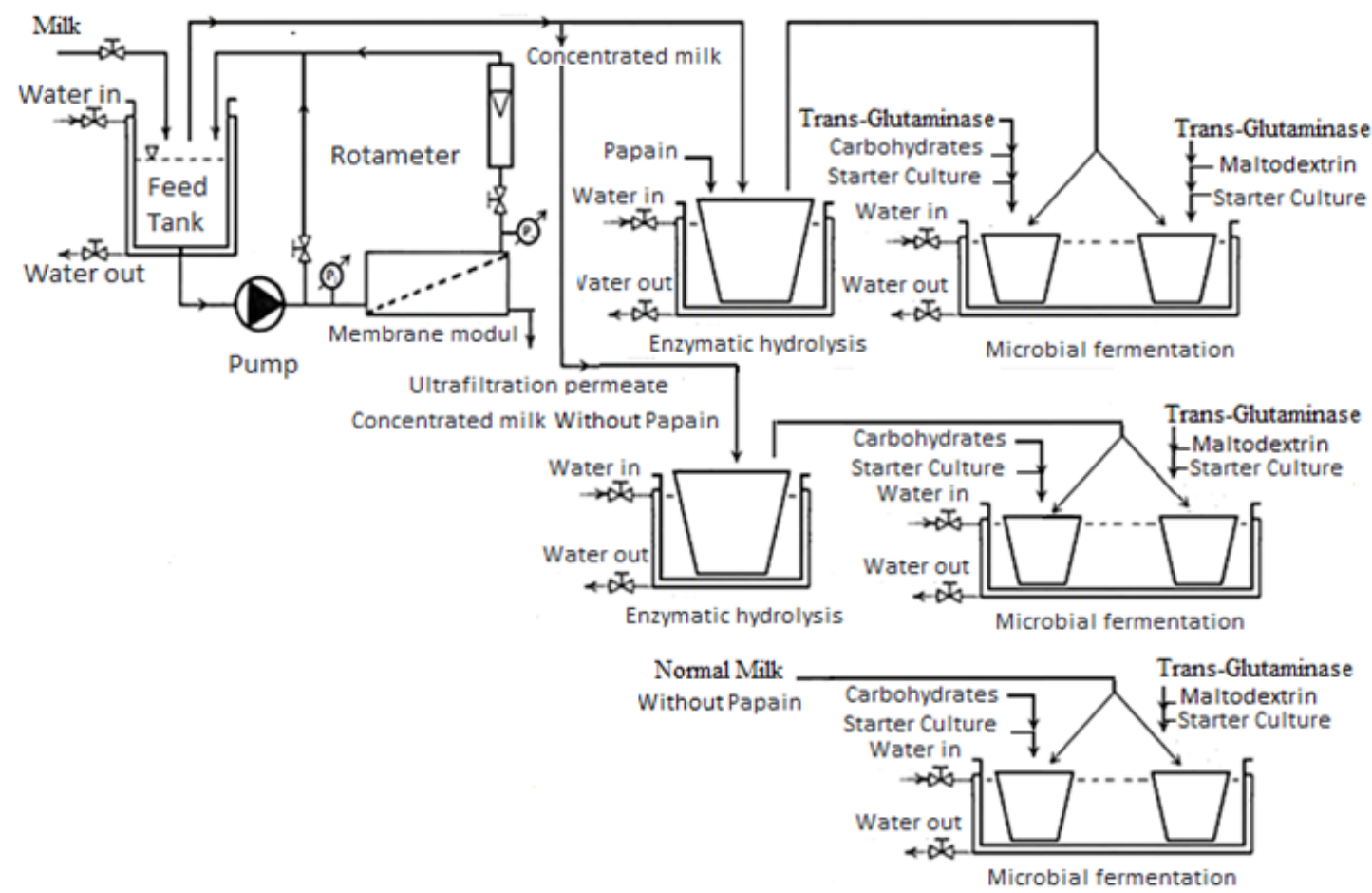

Fig. 1 Process flowsheet for yogurt preparation

with constant temperature $25 \pm 1{ }^{\circ} \mathrm{C}$. Temperature of milk in feed tank was maintained by a thermostat. During the filtration process the transmembrane pressure and the recirculation flow rate were 3 bar and $100 \mathrm{~L} / \mathrm{h}$, respectively.

Before membrane filtration of milk, membrane compaction was performed with transmembrane pressure 4 bar and recirculation flow rate $200 \mathrm{~L} / \mathrm{h}$, until the water flux became steady. After filtration of milk, membrane was cleaned with ultrasil and citric acid in a subsequent way. During cleaning with ultrasil and citric acid, transmembrane pressure 0.8 bar and recirculation flow rate 200 L/h were employed. Finally, membrane was cleaned with de-ionized water. During cleaning with water, transmembrane pressure 5 bar and recirculation flow rate $200 \mathrm{~L} / \mathrm{h}$ were employed [18].

\subsubsection{Enzymatic hydrolysis and fermentation}

In present study, $3 \mathrm{~L}$ of milk was concentrated with membrane and $\sim 1.5 \mathrm{~L}$ of concentrated milk from retentate channel was collected after the end of filtration experiment. Concentrated milk was treated with different concentration of papain, such as $0.0008 \%(\mathrm{w} / \mathrm{v}), 0.0016 \%(\mathrm{w} / \mathrm{v})$, $0.0032 \%(\mathrm{w} / \mathrm{v})$ in separate Erlenmeyer flasks. In each Erlenmeyer flask, sample (concentrated milk) volume was $300 \mathrm{~mL}$. They are designated as N1, N2 and N3, respectively. Enzymatic hydrolysis of milk protein with papain, was performed at temperature $50{ }^{\circ} \mathrm{C}$ for 10 minutes. Subsequently, deactivation of enzyme was performed at temperature $70{ }^{\circ} \mathrm{C}$ for 20 minutes. After deactivation of catalytic activity of papain, the samples were cooled to temperature $45^{\circ} \mathrm{C}$ and subsequently, $45 \mathrm{~mL}$ of papain-treated milk from each category was distributed in $50 \mathrm{~mL}$ of falcon tube. In some cases, $3 \%(\mathrm{w} / \mathrm{v})$ of different types of carbohydrates, such as glucose, sucrose and maltodextrin were added in the respective tubes. Furthermore, in some tubes, $0.002 \%(\mathrm{w} / \mathrm{v})$ transglutaminase, and maltodextrin with transglutaminase were added. Besides that, $45 \mathrm{~mL}$ of membrane retentate concentrated milk was poured into some tubes and similar like before, $3 \%(\mathrm{w} / \mathrm{v})$ of individual carbohydrate was added into them. Normal milk was poured into different falcon tubes with similar fashion. Total 29 samples were generated. Sample codes and their detailed descriptions are mentioned in Table 1. Suspension of yogurt culture was prepared by dissolving 0.18 of lyophilized starter culture with $30 \mathrm{~mL}$ of concentrated milk and subsequently $1 \mathrm{~mL}$ of suspension was inoculated to $45 \mathrm{~mL}$ of milk in each sample tube. All tubes were placed in a water bath at temperature $45{ }^{\circ} \mathrm{C}$ for 6 hours. Subsequently, temperature of all samples was reduced to room temperature $\left(\sim 25^{\circ} \mathrm{C}\right)$ and whey was removed from the top of yogurt. Finally, all samples were placed to a refrigerator at $5^{\circ} \mathrm{C}$ for one day for aging. 
Table 1 Codes and descriptions of yogurt samples

\begin{tabular}{|c|c|c|}
\hline $\begin{array}{l}\text { S1. } \\
\text { no }\end{array}$ & $\begin{array}{l}\text { Sample } \\
\text { codes }\end{array}$ & Description \\
\hline 1 & N1 & $\begin{array}{l}\text { Concentrated milk treated with } 0.0008 \%(\mathrm{w} / \mathrm{v}) \\
\text { of papain }\end{array}$ \\
\hline 2 & $\mathrm{~N} 1+\mathrm{G}$ & $\begin{array}{l}\text { Concentrated milk treated with } 0.0008 \%(\mathrm{w} / \mathrm{v}) \\
\text { of papain + Glucose }\end{array}$ \\
\hline 3 & $\mathrm{~N} 1+\mathrm{S}$ & $\begin{array}{l}\text { Concentrated milk treated with } 0.0008 \%(\mathrm{w} / \mathrm{v}) \\
\text { of papain }+ \text { Sucrose }\end{array}$ \\
\hline 4 & $\mathrm{~N} 1+\mathrm{M}$ & $\begin{array}{c}\text { Concentrated milk treated with } 0.0008 \%(\mathrm{w} / \mathrm{v}) \\
\text { of papain + Maltodextrin }\end{array}$ \\
\hline 5 & $\mathrm{~N} 2$ & $\begin{array}{l}\text { Concentrated milk treated with } 0.0016 \%(\mathrm{w} / \mathrm{v}) \\
\text { of papain }\end{array}$ \\
\hline 6 & $\mathrm{~N} 2+\mathrm{G}$ & $\begin{array}{l}\text { Concentrated milk treated with } 0.0016 \%(\mathrm{w} / \mathrm{v}) \\
\text { of papain + Glucose }\end{array}$ \\
\hline 7 & $\mathrm{~N} 2+\mathrm{S}$ & $\begin{array}{c}\text { Concentrated milk treated with } 0.0016 \%(\mathrm{w} / \mathrm{v}) \\
\text { of papain }+ \text { Sucrose }\end{array}$ \\
\hline 8 & $\mathrm{~N} 2+\mathrm{M}$ & $\begin{array}{l}\text { Concentrated milk treated with } 0.0016 \%(\mathrm{w} / \mathrm{v}) \\
\text { of papain + Maltodextrin }\end{array}$ \\
\hline 9 & N3 & $\begin{array}{l}\text { Concentrated milk treated with } 0.0032 \%(\mathrm{w} / \mathrm{v}) \\
\text { of papain }\end{array}$ \\
\hline 10 & $\mathrm{~N} 3+\mathrm{G}$ & $\begin{array}{l}\text { Concentrated milk treated with } 0.0032 \%(\mathrm{w} / \mathrm{v}) \\
\text { of papain + Glucose }\end{array}$ \\
\hline 11 & $\mathrm{~N} 3+\mathrm{S}$ & $\begin{array}{c}\text { Concentrated milk treated with } 0.0032 \%(\mathrm{w} / \mathrm{v}) \\
\text { of papain + Sucrose }\end{array}$ \\
\hline 12 & $\mathrm{~N} 3+\mathrm{M}$ & $\begin{array}{c}\text { Concentrated milk treated with } 0.0032 \%(\mathrm{w} / \mathrm{v}) \\
\text { of papain + Maltodextrin }\end{array}$ \\
\hline 13 & NM & Normal milk \\
\hline 14 & $\mathrm{NM}+\mathrm{G}$ & Normal milk + Glucose \\
\hline 15 & $\mathrm{NM}+\mathrm{S}$ & Normal milk + Sucrose \\
\hline 16 & $\mathrm{NM}+\mathrm{M}$ & Normal milk + Maltodextrin \\
\hline 17 & N1T & $\begin{array}{l}\text { Concentrated milk treated with } 0.0008 \%(\mathrm{w} / \mathrm{v}) \\
\text { of papain + Transglutaminase }\end{array}$ \\
\hline 18 & $\mathrm{~N} 1 \mathrm{~T}+\mathrm{M}$ & $\begin{array}{l}\text { Concentrated milk treated with } 0.0008 \%(\mathrm{w} / \mathrm{v}) \\
\text { of papain + Transglutaminase + Maltodextrin }\end{array}$ \\
\hline 19 & $\mathrm{~N} 2 \mathrm{~T}$ & $\begin{array}{c}\text { Concentrated milk treated with } 0.0016 \%(\mathrm{w} / \mathrm{v}) \\
\text { of papain }+ \text { Transglutaminase }\end{array}$ \\
\hline 20 & $\mathrm{~N} 2 \mathrm{~T}+\mathrm{M}$ & $\begin{array}{l}\text { Concentrated milk treated with } 0.0016 \%(\mathrm{w} / \mathrm{v}) \\
\text { of papain + Transglutaminase + Maltodextrin }\end{array}$ \\
\hline 21 & N3T & $\begin{array}{l}\text { Concentrated milk treated with } 0.0032 \%(\mathrm{w} / \mathrm{v}) \\
\text { of papain + Transglutaminase }\end{array}$ \\
\hline 22 & $\mathrm{~N} 3 \mathrm{~T}+\mathrm{M}$ & $\begin{array}{l}\text { Concentrated milk treated with } 0.0032 \%(\mathrm{w} / \mathrm{v}) \\
\text { of papain }+ \text { Transglutaminase }+ \text { Maltodextrin }\end{array}$ \\
\hline 23 & NMT & Normal milk + Transglutaminase \\
\hline 24 & $\mathrm{NMT}+\mathrm{M}$ & $\begin{array}{l}\text { Normal milk }+ \text { Transglutaminase } \\
+ \text { Maltodextrin }\end{array}$ \\
\hline 25 & UFM & Ultrafiltered milk \\
\hline 26 & $\mathrm{UFM}+\mathrm{G}$ & Ultrafiltered milk + Glucose \\
\hline 27 & $\mathrm{UFM}+\mathrm{S}$ & Ultrafiltered milk + Sucrose \\
\hline 28 & $\mathrm{UFM}+\mathrm{M}$ & Ultrafiltered milk + Maltodextrin \\
\hline 29 & $\mathrm{UFM}+\mathrm{T}+\mathrm{M}$ & $\begin{array}{l}\text { Ultrafiltered milk + Transglutaminase } \\
+ \text { Maltodextrin }\end{array}$ \\
\hline
\end{tabular}

\subsubsection{Monitoring texture}

Among the texture characteristics, hardness is one of the most important parameters, which is often used to determine the freshness of food. In this study, the hardness is measured by the maximum force (in Newton), which is needed to break the surface of yogurt. The hardness of yogurt was determined by texture analyzer (TA.XT plus, Texture Analyzer, Stable Micro Systems Ltd., England). The yogurt samples were placed in a thermostat, where temperature was maintained $20{ }^{\circ} \mathrm{C}$. The experiment was carried out with a $25 \mathrm{~mm}$ cylinder probe (Patch number 2161). The penetration depth was $5 \mathrm{~mm}$ in every case. The movement of the probe was $1 \mathrm{~mm} / \mathrm{s}$, when it was in air. When the probe touched the superficial surface of yogurt, it's speed turned to $0.1 \mathrm{~mm} / \mathrm{s}$ (test speed). Penetration depth of cylindrical probe within yogurt was $5 \mathrm{~mm}$ with $0.1 \mathrm{~mm} / \mathrm{s}$. Software Exponent (Stable Micro Systems, 2006, version 5.0) was used to calculate force as well as hardness. Around $45 \mathrm{~mL}$ of yogurt sample in each tube was used to analyze hardness of yogurt. The peak force during the first compression cycle is defined as hardness or firmness. Peak force during the $5 \mathrm{~mm}$ compression is represented with Newton unit.

\subsubsection{Antioxidant capacity}

Antioxidant capacity of freshly prepared yogurt samples was measured by the Ferric Reducing Antioxidant Power (FRAP) Assay according to the procedure described by Benzie and Strain with some modifications [19]. From each falcon tube, $10 \mathrm{~g}$ of yogurt were collected and centrifugation was performed with a laboratory centrifuge (Z 206 A Model, Hermle Labortechnik GmbH, Germany). During centrifugation of samples, rotor speed $5600 \mathrm{rpm}$ and temperature $\sim 25^{\circ} \mathrm{C}$ were used for $20 \mathrm{~min}$ utes. Subsequently, $1 \mathrm{~mL}$ of supernatant was collected for assay. In assay, $300 \mathrm{mM}$ of sodium acetate buffer (pH 3.6), $20 \mathrm{mM}$ of ferric chloride and 2,4,6-Tripyridyl-STriazineAscorbic acid solution (10 mM 2,4,6-TripyridylS-Triazine with $40 \mathrm{mM}$ of hydrochloric acid) were mixed with the ratio 10:1:1. $9 \mathrm{~mL}$ of freshly prepared reagent was mixed with $1 \mathrm{~mL}$ of appropriate diluted sample and all test tubes were incubated for $30 \mathrm{~min}$ at temperature $37^{\circ} \mathrm{C}$. Ascorbic acid was used as reference. After incubation, the absorbance of the samples was measured with a spectrophotometer (DR/2400 Portable Spectrophotometer, Hach, USA). Spectrophotometric measurement was performed with $593 \mathrm{~nm}$ of wavelength. 


\section{Results and discussion}

\subsection{Membrane filtration}

The composition of cow's milk is represented in Table 2. In first step, milk was concentrated by ultrafiltration membrane. It was observed that permeate flux was declined with increase of the VCR (Fig. 2). With increase of VCR, permeate flux was reduced due to formation of concentration polarization on membrane surface. As membrane separation process was performed with $5 \mathrm{~nm}$ membrane and batch-mode process, protein concentration was increased in retentate side along with filtration time. Concentrated proteins were deposited on membrane surface and gel layer resistance was increased with time progress. In Fig. 2, it is shown that the initial value of permeate flux was $37 \mathrm{~L} /\left(\mathrm{m}^{2} \times \mathrm{h}\right)$ which was declined to $24 \mathrm{~L} /\left(\mathrm{m}^{2} \times \mathrm{h}\right)$ when $\mathrm{VCR}$ reach to 2 . In present investigation, static turbulence promoter was applied inside of membrane tube to reduce the formation of concentration polarization on membrane surface. It created turbulence on membrane surface, which offered tangential force on membrane surface. On the other hand, trans-membrane pressure offered driving force on membrane surface. Combination of these two forces, formation of concentration polarization and gel-layer resistance were reduced. In the present investigation, membrane with pore size $5 \mathrm{~nm}$ was used. It increased the concentration of proteins in retentate end of membrane module.

Table 2 Average composition of the Cow's milk, according to Naszálytej Tejfeldolgozó és Kereskedelmi Zrt, Hungary

\begin{tabular}{lc}
\hline Component & Concentration in $\%(\mathrm{w} / \mathrm{v})$ \\
\hline Fat & 1.5 \\
Protein & 2.9 \\
Lactose & 4.6 \\
Minerals & 0.13 \\
\hline
\end{tabular}

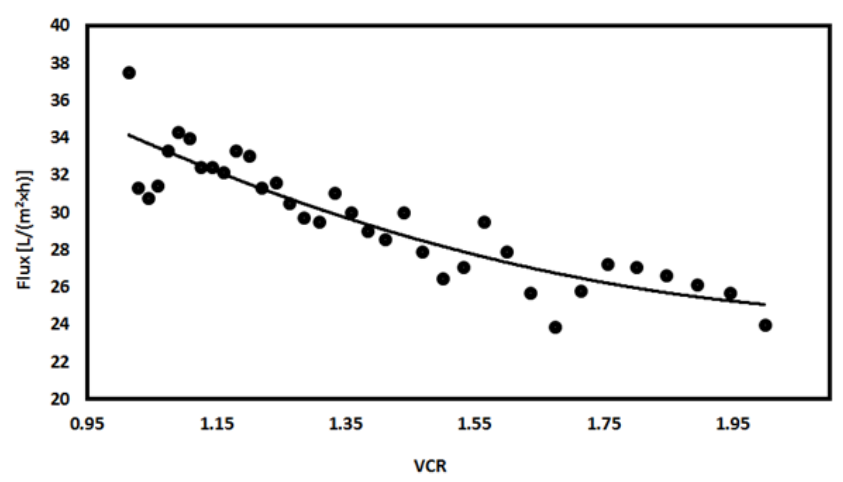

Fig. 2 Permeate flux during membrane filtration of milk

\subsection{Texture analysis}

Results of harness of yogurt samples are represented in Table 3. Hardness of yogurt, prepared by normal milk was 0.58 Newton and it was increased when yogurt was prepared with concentrated milk. This is justified by the fact that high solid (milk protein) concentration in ultrafiltered-milk increased the viscosity as well as hardness of yogurt samples [20, 21]. Hardness of yogurt, prepared with carbohydrate addition was increased compare to yogurt, prepared without carbohydrate. This can be justified by the fact that yogurt starter cultures, namely Lactobacillus bulgaricus and Streptococcus thermophilus produced exo-polysaccharides from carbohydrate, which have potential contribution to impart smooth texture, higher viscosity and lower syneresis [22, 23]. It has

Table 3 Hardness of different types of yogurts

\begin{tabular}{|c|c|c|}
\hline S1. no & Sample codes & Hardness (Newton) \\
\hline 1 & N1 & 1.58 \\
\hline 2 & $\mathrm{~N} 1+\mathrm{G}$ & 1.53 \\
\hline 3 & $\mathrm{~N} 1+\mathrm{S}$ & 1.07 \\
\hline 4 & $\mathrm{~N} 1+\mathrm{M}$ & 1.5 \\
\hline 5 & N2 & 1.94 \\
\hline 6 & $\mathrm{~N} 2+\mathrm{G}$ & 2.08 \\
\hline 7 & $\mathrm{~N} 2+\mathrm{S}$ & 1.74 \\
\hline 8 & $\mathrm{~N} 2+\mathrm{M}$ & 1.8 \\
\hline 9 & N3 & 1.43 \\
\hline 10 & $\mathrm{~N} 3+\mathrm{G}$ & 2.03 \\
\hline 11 & $\mathrm{~N} 3+\mathrm{S}$ & 1.73 \\
\hline 12 & $\mathrm{~N} 3+\mathrm{M}$ & 1.75 \\
\hline 13 & NM & 0.58 \\
\hline 14 & $\mathrm{NM}+\mathrm{G}$ & 0.59 \\
\hline 15 & $\mathrm{NM}+\mathrm{S}$ & 0.59 \\
\hline 16 & $\mathrm{NM}+\mathrm{M}$ & 0.65 \\
\hline 17 & N1T & 1.8 \\
\hline 18 & $\mathrm{~N} 1 \mathrm{~T}+\mathrm{M}$ & 1.9 \\
\hline 19 & $\mathrm{~N} 2 \mathrm{~T}$ & 2 \\
\hline 20 & $\mathrm{~N} 2 \mathrm{~T}+\mathrm{M}$ & 1.9 \\
\hline 21 & N3T & 2.6 \\
\hline 22 & $\mathrm{~N} 3 \mathrm{~T}+\mathrm{M}$ & 2.7 \\
\hline 23 & NMT & 0.73 \\
\hline 24 & $\mathrm{NMT}+\mathrm{M}$ & 0.7 \\
\hline 25 & UFM & 1.5 \\
\hline 26 & $\mathrm{UFM}+\mathrm{G}$ & 1.9 \\
\hline 27 & UFM+S & 1.65 \\
\hline 28 & $\mathrm{UFM}+\mathrm{M}$ & 1.6 \\
\hline 29 & $\mathrm{UFM}+\mathrm{T}+\mathrm{M}$ & 1.8 \\
\hline
\end{tabular}


been reported that exo-polysaccharide yield from the species of Streptocuccus thermophilus was $\sim 1,029 \mathrm{mg} / \mathrm{L}$ in milk medium in presence of $0.5 \%$ whey protein concentrate [24]. Furthermore, intrinsic viscosity, ranging from 1.5-4.7 dL/g had been reported for exo-polysaccharides, produced by starter culture Streptocuccus thermophilus and Lactobacillus bulgaricus [25]. Transglutaminase also had a positive effect on the hardness of yogurt. This can be justified by the fact that transglutaminase promoted cross-linking of amino acids lysine and glutamine in protein chain, which reduced the loss of whey proteins, increased the solid content (protein) in yogurt and developed tight protein network. As a result, hardness of yogurt was increased [12, 20].

\subsection{Antioxidant capacity}

The aim of this study was to examine the antioxidant capacity of different types of yogurt samples. Antioxidant capacity of different types of yogurts is represented in Fig. 3. Antioxidant capacity in yogurt, prepared by conventional method was $0.44 \mathrm{mmol}$ eqv. ascorbic acid/L. It was increased in yogurt, prepared with papain compare to normal cow's milk yogurt. Papain prefers to cut at (hydrophobic amino acid)-(Arg or Lys or Glu or His or Gly or Tyr) in milk protein [26, 27]. With increase of the concentration of papain, more amounts of peptide bonds in milk proteins were cleaved and hydrophobic amino acids were exposed. Hydrophobic amino acids in peptide chain offer antioxidant capacity [28].

Antioxidant capacity in yogurt samples, prepared with transglutaminase was increased compare to yogurt sample, prepared with normal milk. This can be justified by the fact that cross-linking of amino acids lysine and glutamine in protein chain was done in presence of transglutaminase. It reduced the loss of whey proteins, where hydrophobic amino acids were present at terminal end. Furthermore, addition of carbohydrate increased the antioxidation capacity of yogurt samples because during microbial fermentation, exo-polysaccharides were produced from carbohydrate by starter cultures, which increased the water holding capacity in yogurt [29].

\section{References}

[1] Sarkar, S. "Potentiality of probiotic yoghurt as a functional fooda review", Nutrition \& Food Science, 49(2), pp. 182-202, 2019. https://doi.org/10.1108/NFS-05-2018-0139

[2] Sánchez, A., Vázquez, A. "Bioactive peptides: A review", Food Quality and Safety, 1(1), pp. 29-46, 2017.

https://doi.org/10.1093/fqs/fyx006

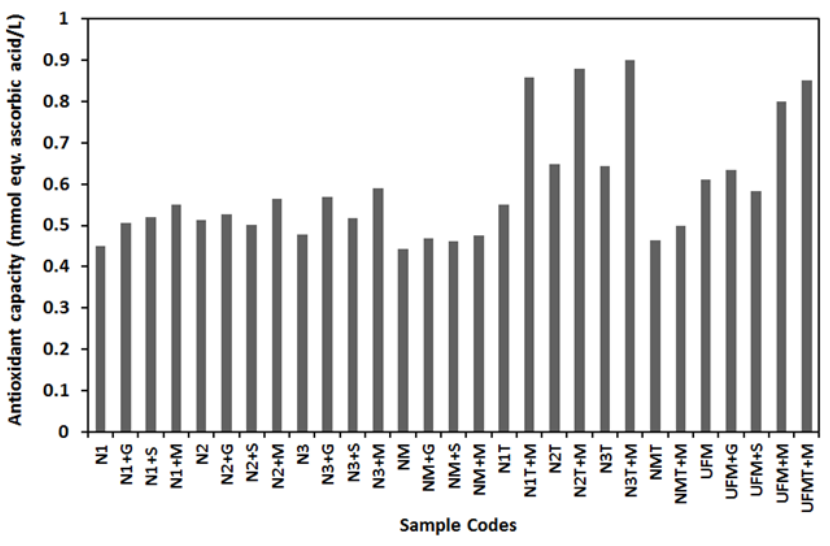

Fig. 3 Antioxidant capacity of different yogurt samples

During enzymatic hydrolysis of milk proteins with papain, low molecular weight of peptides with antioxidant capacity were produced and they were present in whey. Due to increase of water holding capacity in presence of exo-polysaccharides, loss of antioxidant peptides through whey separation was reduced and antioxidant capacity was increased in yogurt samples.

\section{Conclusion}

Yogurt is considered as a functional food which is a complex heterogeneous system containing different biological components. The study reveals that antioxidant capacity was increased due to enzymatic hydrolysis of milk proteins with papain. Application of carbohydrate offered higher hardness and antioxidant capacity in yogurt. Furthermore, antioxidant capacity and hardness in yogurt samples were increased due to application of transglutaminase.

It is expected that this new process technology may open a new arena in functional food development in dairy industry. Further studies are required to understand the other biochemical activities of prepared yogurt.

\section{Acknowledgement}

The research was supported by the Szent István University, Doctoral School of Food Science and the European Union and co-financed by the European Social Fund (grant agreement no. EFOP-3.6.3-VEKOP-16-2017-00005).

[3] Wal, J. M. "Bovine milk allergenicity", Annals of Allergy, Asthma \& Immunology, 93(5), pp. S2-S11, 2004. https://doi.org/10.1016/s1081-1206(10)61726-7

[4] Hochwallner, H., Schulmeister, U., Swoboda, I., Spitzauer, S., Valenta, R. "Cow's milk allergy: From allergens to new forms of diagnosis, therapy and prevention", Methods, 66(1), pp. 22-33, 2014. https://doi.org/10.1016/j.ymeth.2013.08.005 
[5] Khan, I. T., Nadeem, M., Imran, M., Ullah, R., Ajmal, M., Jaspal, M. H. "Antioxidant properties of Milk and dairy products: a comprehensive review of the current knowledge", Lipids in Health and Disease, 18(1), Article number: 41, 2019.

https://doi.org/10.1186/s12944-019-0969-8

[6] Khan, I. T., Bule, M., Ullah, R., Nadeem, M., Asif, S., Niaz, K. "The antioxidant components of milk and their role in processing, ripening, and storage: Functional food", Veterinary World, 12(1), pp. 12-33, 2019.

https://doi.org/10.14202/vetworld.2019.12-33

[7] Uduwerella, G., Chandrapala, J., Vasiljevic, T. "Preconcentration of yoghurt base by ultrafiltration for reduction in acid whey generation during Greek yoghurt manufacturing", International Journal of Dairy Technology, 71(1), pp. 71-80, 2018.

https://doi.org/10.1111/1471-0307.12393

[8] Magenis, R. B., Prudêncio, E. S., Amboni, R. D. M. C., Cerqueira Júnior, N. G., Oliveira, R. V. B., Soldi, V., Benedet, H. D. "Compositional and physical properties of yogurts manufactured from milk and whey cheese concentrated by ultrafiltration", International Journal of Food Science \& Technology, 41(5), pp. 560-568, 2006.

https://doi.org/10.1111/j.1365-2621.2005.01100.x

[9] Nath, A., Chakraborty, S., Bhattacharjee, C., Chowdhury, R. "Studies on the separation of proteins and lactose from casein whey by cross-flow ultrafiltration", Desalination and Water Treatment, 54(2), pp. 481-501, 2015.

https://doi.org/10.1080/19443994.2014.888685

[10] Giacobbo, A., Moura Bernardes, A., Filipe Rosa, M. J., De Pinho, M. N. "Concentration Polarization in Ultrafiltration/ Nanofiltration for the Recovery of Polyphenols from Winery Wastewater", Membranes, 8(3), Article number: 46, 2018. https://doi.org/10.3390/membranes8030046

[11] Varga, Á., Gáspár, I., Juhász, R., Ladányi, M., Hegyes-Vecseri, B., Kókai, Z., Márki, E. "Beer microfiltration with static turbulence promoter: Sum of ranking differences comparison", Journal of Food Process Engineering, 42(1), Article number: e12941, 2019. https://doi.org/10.1111/jfpe.12941

[12] Darnay, L., Koncz, Á., Gelencsér, É., Pásztor-Huszár, K., Friedrich, L. "Textural properties of low-fat set-type yoghurt depending on mTG addition", Mljekarstvo, 66(3), pp. 225-230, 2016. https://doi.org/10.15567/mljekarstvo.2016.0307

[13] Ziarno, M., Zaręba, D. "The effect of the addition of microbial transglutaminase before the fermentation process on the quality characteristics of three types of yogurt", Food Science and Biotechnology, 29(1), pp. 109-119, 2020. https://doi.org/10.1007/s10068-019-00640-6

[14] Amri, E., Mamboya, F. "Papain, a Plant Enzyme of Biological Importance: A Review", American Journal of Biochemistry and Biotechnology, 8(2), pp. 99-104, 2012. https://doi.org/10.3844/ajbbsp.2012.99.104

[15] Alpay, P., Aktaş Uygun, D. "Usage of immobilized papain for enzymatic hydrolysis of proteins", Journal of Molecular Catalysis B: Enzymatic, 111, pp. 56-63, 2015.

https://doi.org/10.1016/j.molcatb.2014.11.001
[16] Nath, A., Kailo, G. G., Mednyánszky, Z., Kiskó, G., Csehi, B., Pásztorné-Huszár, K., Gerencsér-Berta, R., Galambos, I., Pozsgai, E., Bánvölgyi, S., Vatai, G. "Antioxidant and Antibacterial Peptides from Soybean Milk through Enzymatic- and MembraneBased Technologies", Bioengineering, 7(1), Article number: 5, 2020. https://doi.org/10.3390/bioengineering7010005

[17] Banvolgyi,S.,Bahceci,K.S., Vatai,G.,Bekassy,S.,Bekassy-Molnar,E. "Partial dealcoholization of red wine by nanofiltration and its effect on anthocyanin and resveratrol levels", Food Science and Technology International, 22(8), pp. 677-687, 2016. https://doi.org/10.1177/1082013216642331

[18] Nath, A., Szécsi, G., Csehi, B., Mednyánszky, Z., Kiskó, G., Bányai, É., Dernovics, M., Koris, A. "Production of Hypoallergenic Antibacterial Peptides from Defatted Soybean Meal in Membrane Bioreactor: A Bioprocess Engineering Study with Comprehensive Product Characterization", Food Technology \& Biotechnology, 55(3), pp. 308-324, 2017.

https://doi.org/10.17113/ftb.55.03.17.5040

[19] Benzie, I. F. F., Strain, J. J. "Ferric reducing/antioxidant power assay: Direct measure of total antioxidant activity of biological fluids and modified version for simultaneous measurement of total antioxidant power and ascorbic acid concentration", Methods Enzymology, 299, pp. 15-27, 1999. https://doi.org/10.1016/s0076-6879(99)99005-5

[20] Pakseresht, S., Mazaheri Tehrani, M., Razavi, S. M. A. "Optimization of low-fat set-type yoghurt: effect of altered whey protein to casein ratio, fat content and microbial transglutaminase on rheological and sensorial properties", Journal of Food Science and Technology, 54(8), pp. 2351-2360, 2017. https://doi.org/10.1007/s13197-017-2675-8

[21] Jaros, D., Rohm, H. "Controlling the texture of fermented dairy products: the case of yoghurt", In: Smit, G. (ed.) Dairy Processing: Improving Quality, Woodhead Publishing Series in Food Science, Technology and Nutrition, Cambridge, UK, 2003, pp. 155-184. https://doi.org/10.1533/9781855737075.1.155

[22] Vedamuthu, E. R. "Starter Cultures for Yogurt and Fermented Milks", In: Chandan, R. C., White, C. H., Kilara, A., Hui, Y. H. (eds.) Manufacturing Yogurt and Fermented Milks, Blackwell Publishing, Ames, IA, USA, 2006, pp. 89-116. https://doi.org/10.1002/9780470277812.ch6

[23] Boels, I. C., Kleerebezem, M., de Vos, W. M. "Engineering of Carbon Distribution between Glycolysis and Sugar Nucleotide Biosynthesis in Lactococcus lactis", Applied and Environmental Microbiology, 69(2), pp. 1129-1135, 2003. https://doi.org/10.1128/AEM.69.2.1129-1135.2003

[24] Zisu, B., Shah, N. P. "Effects of pH, Temperature, Supplementation with Whey Protein Concentrate, and Adjunct Cultures on the Production of Exopolysaccharides by Streptococcus thermophilus 1275", Journal of Dairy Science, 86(11), pp. 3405-3415, 2003. https://doi.org/10.3168/jds.S0022-0302(03)73944-7

[25] Zourari, A., Accolas, J. P., Desmazeaud, M. J. "Metabolism and biochemical characteristics of yogurt bacteria. A review", Le Lait, 72(1), pp. 1-34, 1992.

https://doi.org/10.1051/lait:199211 
[26] Acquah, C., Di Stefano, E., Udenigwe, C. C. "Role of hydrophobicity in food peptide functionality and bioactivity", Journal of Food Bioactives, 4, pp. 88-98, 2018.

https://doi.org/10.31665/JFB.2018.4164

[27] Cstorer, A., Ménard, R. "Catalytic mechanism in papain family of cysteine peptidases", Methods in Enzymology, 244, pp. 486-500, 1994.

https://doi.org/10.1016/0076-6879(94)44035-2
[28] Fernández-Lucas, J., Castañeda, D., Hormigo, D. "New trends for a classical enzyme: Papain, a biotechnological success story in the food industry", Trends in Food Science \& Technology, 68, pp. 91-101, 2017.

https://doi.org/10.1016/j.tifs.2017.08.017

[29] Buldo, P., Benfeldt, C., Folkenberg, D. M., Jensen, H. B., Amigo, J. M., Sieuwerts, S., Thygesen, K., van den Berg, F., Ipsen, R. "The role of exopolysaccharide-producing cultures and whey protein ingredients in yoghurt", LWT - Food Science and Technology, 72, pp. 189-198, 2016.

https://doi.org/10.1016/j.1wt.2016.04.050 